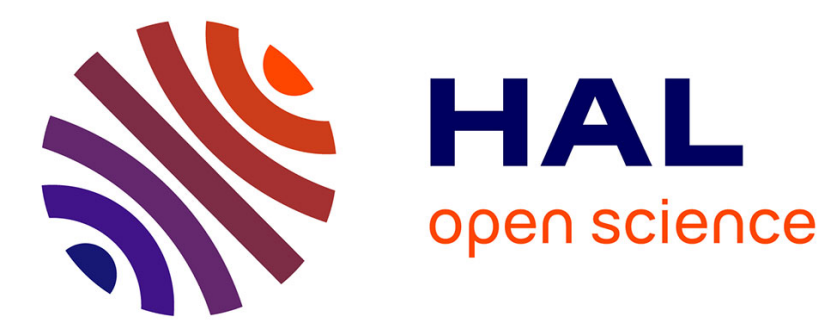

\title{
(De-)Politicising women's collective action: international actors and land inheritance in post-war Burundi
}

\author{
Marie Saiget
}

\section{To cite this version:}

Marie Saiget. (De-)Politicising women's collective action: international actors and land inheritance in post-war Burundi. Review of African Political Economy, 2016, Review of African Political Economy, 43 (149), pp.365-381. 10.1080/03056244.2016.1214113 . hal-02551740

\section{HAL Id: hal-02551740 \\ https://hal.univ-lille.fr/hal-02551740}

Submitted on 30 Apr 2020

HAL is a multi-disciplinary open access archive for the deposit and dissemination of scientific research documents, whether they are published or not. The documents may come from teaching and research institutions in France or abroad, or from public or private research centers.
L'archive ouverte pluridisciplinaire HAL, est destinée au dépôt et à la diffusion de documents scientifiques de niveau recherche, publiés ou non, émanant des établissements d'enseignement et de recherche français ou étrangers, des laboratoires publics ou privés. 


\title{
(De-)politicising women's collective action. International actors and land inheritance in post-war Burundi
}

\author{
Marie Saiget
}

\begin{abstract}
This article focuses on women's collective action promoting land inheritance in Burundi. It aims to discuss the role of international actors in social transformations, questioning to what extent they have shaped women's collective action since the 1970s, in particular since the country's president took the official decision to stop the legislative and political process for adopting a law in 2011. The article argues that international actors are a central factor in (de- )politicisation by playing the role of a third party in the relationship between women's associations and the state. These interactions produce a particular form of mobilisation that promotes law as a tool to build, frame and provide answers to the land issue.
\end{abstract}

Keywords: women's collective action, land inheritance, international actors, politicisation, Burundi

\section{Résumé}

[(Dé-)Politiser l'action collective féminine. Les acteurs internationaux et la succession des femmes à la terre au Burundi de l'après-guerre.]

Cet article traite de l'action collective féminine sur la succession des femmes à la terre au Burundi. Il interroge le rôle des acteurs internationaux dans les transformations sociales de l'après-guerre, en se demandant dans quelle mesure ces derniers ont influencé l'action collective féminine depuis les années 1970, et en particulier depuis que le président burundais a pris la décision de mettre fin au processus politique et législatif d'adoption d'une loi sur la succession. L'article montre que les acteurs internationaux sont un facteur central de (dé-)politisation en jouant le rôle de tiers dans la relation entre les associations de femmes et l'État. Ces interactions produisent une forme particulière de mobilisation qui promeut le droit comme outil de construction, de cadrage et de résolution de la question foncière.

Mots-clés : action collective féminine, succession à la terre, acteurs internationaux, politisation, Burundi 


\section{Introduction}

Women's right to inherit land has given rise to major controversies in Burundi since the civil war (1993-2006). Women should be able to enjoy this right like their brothers, say women activists who promote the adoption of a law on land inheritance. Indeed, women's exclusion from land inheritance ${ }^{i}$ not only has negative consequences on their economic power, preventing them from accessing, controlling and managing land and land resources, but it also makes them particularly vulnerable to polygamy and domestic violence (Association des Femmes Juristes du Burundi and Association des Juristes Catholiques du Burundi [AFJB/AJCB, the Association of Women Jurists of Burundi and Association of Catholic Jurists of Burundi respectively] 2012, 42-46). Opponents of such change cite factors such as land pressure, respect for custom based on the patrilineal system, and clan divisions. Land is the main dimension of family, ethnic and clan identity (Daley 2008; Uvin 2009), and is already the object of many local conflicts. ${ }^{\text {ii }}$ Finally, urban and educated women activists' ability to speak for rural women, whose relations to land are not limited to inheritance, is questioned.

As this debate illustrates, inheritance seems in Burundi - as in other African countries - to be ' $[\mathrm{t}]$ he biggest problem in the whole debate about statutory reform and women's rights to land' (McAuslan 2010, 125). It highlights economic and social cleavages, rural and urban divide, gender relations and divisions between women. As this article shows, this is also indicative of political and legislative change, as well as of power relations between the state and social movements.

This controversy is even more tense in post-war contexts as several issues may add complexity to the process of land reform, such as restitution (McAuslan 2010, 116). In Burundi, the land issue has indeed been highly politicised since the civil war, which 'deprived hundreds of thousands of refugees and displaced people of their properties' (International Crisis Group 2014).

The idea of codifying land inheritance emerged long before the 1990s. It was framed as a women's rights issue in 1975 in the context of the United Nations Decade for Women (197685) and became a key issue for Burundian women's movements. Since then, some United Nations (UN) agencies and non-governmental organisations (NGOs) working on women's issues in Burundi have indirectly influenced, as well as actively supported, women's collective action on land inheritance. The weight of international agendas on social, economic and land reforms thus deserves scrutiny. Nevertheless, no law has yet been adopted, which highlights continuing resistance to women's property rights and access to land, including at a political level under the current government ruled by the Conseil national pour la défense de la démocratie-Forces de défense de la démocratie (CNDD-FDD, National Council for the Defence of Democracy-Forces for the Defence of Democracy) party, since the president, Pierre Nkurunziza, decided in 2011 to stop the legislative and political process around the adoption of legislation on women's inheritance rights.

This article addresses women's collective action ${ }^{\text {iii }}$ promoting women's right to inherit land. Using the case of Burundi (1975-2015), it aims to discuss the role of international actors in campaigning for legislative change in post-war contexts. More precisely, it studies processes of politicisation by answering the following questions: why has women's collective action on land inheritance not succeeded? To what extent have international actors shaped and politicised women's collective action? What does this case tell us about the relationship between civil society organisations (CSOs) and the state in post-war settings?

Drawing on fieldwork conducted in Burundi from 2012 to $2014^{\mathrm{iv}}$ and an analysis of UN and NGO reports, this article gives an account of the complex interactions of legal, political and civil society institutions that shape land law in Burundi. Defining politicisation as a process of confrontation and negotiation with state authorities (Tilly 1978), I study how these interactions 
politicise, de-politicise and even re-politicise women's collective action on land inheritance. This process is examined in light of cleavages and systems of political alliances and support among the actors, groups and individuals that campaign for land inheritance. I argue that international actors are a central factor of (de-)politicisation by playing the role of a third party in the relationship between women's associations and the state. These interactions produce a particular form of mobilisation that promotes law as a tool to build, frame and resolve (or fail to resolve) the land issue.

The first section presents a conceptual framework for the study of interactions of actors shaping land law in post-war contexts. The second section analyses the Burundian case by addressing the evolution of interactions between women's associations, international actors and the state on the issue of women's inheritance to land.

\section{Conceptual framework: complex interactions shaping land law in post-war contexts}

Critical perspectives on development and peacebuilding constitute a relevant body of literature to study the influence of international interventions on social transformations, focusing on power relations between the state, society and external actors in these fields (Hearn 1998; Kothari and Minogue 2002; Abrahamsen 2004; Richmond and Mitchell 2012). Moreover, the argument of de-politicisation brought first by James Ferguson (Ferguson 1994) has increasingly been addressed and discussed by critical works on the influence of global norms on gender on women's movements (Jad 2007; Cornwall and Eade 2010; Fuest 2010; Cornwall and Edwards 2014). Nevertheless, little has been said about the social mechanisms of de-politicisation, as if speaking of 'development' or 'peace' would automatically de-politicise local discourses and practices. This implies a view of international agendas as homogenous, consistent and effectively implemented. Yet, discrepancy between goals and practices should not be interpreted as the result of an externally imposed agenda on land in Burundi, ${ }^{\mathrm{v}}$ but as the product of uncoordinated mobilisations of international, national and local actors. First, '[h] umanitarian agencies have only recently begun to grapple with land issues, and the specifics of women's land rights in immediate post-conflict situations have yet to be seriously addressed' (Daley and Englert 2010, 94). Second, while current debates on land rights and reforms take place in the context of interventions by the international financial institutions, bilateral donors, the UN and NGOs seeking to manage and regulate the globalisation process in Africa (Bush and Szeftel 2000, 174), these actors have been pursuing disparate agendas and strategies, particularly on gender issues. In Burundi, international actors working on land issues have oscillated from the absence of position on land inheritance (the Word Bank, and the Food and Agriculture Organization integrated gender issues very marginally in their programmes) to informal reluctance (International Fund for Agricultural Development) (field notebook, Bujumbura, February and March 2014). Only the international actors that focus on gender equality or women's empowerment like UNIFEM/UN Women and NGOs like International Alert, Agency for Cooperation and Research in Development (ACORD) and CARE International have directly addressed women's rights and access to land in Burundi.

To analyse the process of (de-)politicisation, I focus on alliances and group formation and question two aspects of women's collective action: the various strategic uses of legal mobilisation as a repertoire of action across time; and the post-war context as a window of opportunity (or not) for legislative reforms. The study of alliances and group formation questions women's solidarity and their ability to participate in several spheres of power. On the one hand, the process of group formation is a particularly relevant topic to investigate as women do not constitute a homogeneous category (Goetz and Hassim 2003). Then, keeping in mind 
that women's political representation does not equal 'effective' political participation or engagement in favour of gender or women's issues, I look at the relations among women evolving both in activist social space and political or partisan space. On the other hand, the contingent dimension of alliances and political strategies must be highlighted in order to 'identify the fluctuating relations characterised by relative and evolving autonomy that unite social movements and institutional politics' (Lilian Mathieu, in Fillieule, Agrikoliansky, and Sommier 2010, 51).

First, this article questions the impact of fluctuating political relations between international actors, women's groups and the state on the choice and use of legislative campaign. In other words, it is about understanding how repertoires of action have changed over time and what the consequences are on the process of politicisation. In the present case, the concept of 'legal mobilisation' - developed by Michael McCann when discussing social movement reliance on legal norms and practices (McCann 1994) - refers to the lobbying strategies of women's associations in coalition with other actors, such as international organisations and NGOs, to push for legislative reform. The goal is not to discuss either social movement theory or the concept of 'legal mobilisation' but to use them as a toolbox to investigate how women's rights discourse and legislative campaigning have worked as a particular framing and a repertoire of action that have opened a political space and provided strategic resources for actors seeking gender equality in land property rights. In this respect, Burundi is a relevant and as yet unexplored case of legal mobilisation in post-war contexts. It is in line with studies on women's rights to land in eastern Africa concluding with the slow and erratic process of securing women's land rights despite the existence of land tenure reforms (Tripp, Casimiro, and Kwesiga 2009; Daley, Dore-Weeks, and Umuhoza 2010; Naybor 2014). But it focuses on the particularities of these social movements in the making, land inheritance being a driving issue for women's collective action.

Second, the article considers the role of contexts. In particular, I discuss post-war situations and political transitions as windows of opportunity for change (Goetz and Hassim 2003). This was the case in Eritrea, where the land issue was addressed as part of the broader package of 'post-war recovery and reconstruction' (Rock 2000), or in Rwanda where a law was passed on gender equality in land inheritance in 1999 as a result of women's peace activism (Daley et al. 2010). In Burundi, however, it did not play in favour of a law on land inheritance, which deserves a specific explanation. Indeed, 'the ambitious land reform provided for in the Arusha agreement signed on 28 August $2000 \ldots$ has been superficial' (Ibid.), even silent, on gender issues. Furthermore, peace is never a once-and-for-always achievement, especially in light of the political crisis that broke out in Burundi in spring 2015. Therefore, the Burundian post-war context conceptually refers to a 'peace in between' (Berdal and Suhrke 2012,6) or else, as suggested by the political trajectory of Burundi since 1993 (see Reyntjens 2006; Vandeginste 2009), to an 'interwar period', defined as 'a situation where people [...] are waiting for the next year hoping that it [war] will not break out' (Debos 2013, 26).

In the following section, I bring a historical perspective on legal mobilisation with the case of Burundi, going through the evolution of the relationship between international actors, women's associations and the state on land inheritance from 1975 to 2015. 


\section{A historical perspective on legal mobilisation}

I identify three different phases highlighting the role played by international actors in shaping women's collective action on the land issue as legal mobilisation (see Table 1).

Table 1. The chronology of women's collective action on land inheritance in Burundi.

\begin{tabular}{|c|c|c|c|}
\hline & $\begin{array}{c}\text { 1st phase: } 1975-2002 \\
\text { Emergence }\end{array}$ & $\begin{array}{r}\text { 2nd phase: } 2002-11 \\
\text { Development }\end{array}$ & $\begin{array}{c}\text { 3rd phase: } 2011-15 \\
\text { Survival }\end{array}$ \\
\hline $\begin{array}{l}\text { Agendas and } \\
\text { actors }\end{array}$ & $\begin{array}{l}\text { Single party women's } \\
\text { organisation: Union } \\
\text { des Femmes } \\
\text { Burundaises (UFB) } \\
(1975-87) . \\
\text { Parliament (1977-93). } \\
\text { Human rights and } \\
\text { women's associations } \\
\text { (1991-). }\end{array}$ & $\begin{array}{l}\text { Travelling back and } \\
\text { forth between } \\
\text { Association des } \\
\text { Femmes Juristes du } \\
\text { Burundi (AFJB), the } \\
\text { parliament and the } \\
\text { government (2002- } \\
\text { 2004). } \\
\text { Presidential agenda } \\
\text { (2006) } \\
\text { International support and } \\
\text { projects (2009-2012) }\end{array}$ & $\begin{array}{l}\text { Women's } \\
\text { associations, } \\
\text { NGOs and UN } \\
\text { Women. } \\
\text { International } \\
\text { advocacy (2011- } \\
2014)\end{array}$ \\
\hline $\begin{array}{l}\text { Alliances and } \\
\text { systems of } \\
\text { support }\end{array}$ & $\begin{array}{l}\text { Fusion until the late } \\
\text { 1980s (no distinction } \\
\text { between civil/social } \\
\text { and political spaces). } \\
\text { Collaboration between } \\
\text { women in politics and } \\
\text { women activists } \\
\text { during the 1990s. }\end{array}$ & $\begin{array}{l}\text { Alliances between } \\
\text { women in politics and } \\
\text { women activists } \\
\text { Civil society coalition. }\end{array}$ & $\begin{array}{l}\text { Divisions between } \\
\text { women from } \\
\text { political and civil } \\
\text { spheres. } \\
\text { Civil society } \\
\text { coalition } \\
\text { challenged. } \\
\text { Disconnection } \\
\text { between rural and } \\
\text { urban women. }\end{array}$ \\
\hline $\begin{array}{l}\text { Specific role } \\
\text { and influence } \\
\text { of } \\
\text { international } \\
\text { actors }\end{array}$ & $\begin{array}{l}\text { Indirect and diffuse } \\
\text { influence (through } \\
\text { norms and } \\
\text { international and } \\
\text { regional conferences) }\end{array}$ & $\begin{array}{l}\text { Supportive role } \\
\text { (providing material, } \\
\text { technical and } \\
\text { normative resources) }\end{array}$ & $\begin{array}{l}\text { Conflicting third } \\
\text { party in the } \\
\text { relationship } \\
\text { between women's } \\
\text { associations and } \\
\text { the state }\end{array}$ \\
\hline $\begin{array}{l}\text { Politics of } \\
\text { legal } \\
\text { mobilisation }\end{array}$ & Institutional politics & Institutional politics & $\begin{array}{l}\text { Contentious politics } \\
\text { Political exploitation }\end{array}$ \\
\hline
\end{tabular}


First phase: the long and erratic emergence of the women's land inheritance issue (19752002)

As suggested by Table 1, the emergence of women's collective action on land issues should be divided into two sub-phases: the first one describing the period before the civil war (from 1975 to 1993), and the second referring to the civil war (from 1993 to 2002). I then closely examine the interactions between the international, regional and national levels in the building of women's collective action.

\section{UFB women's activism and the agenda of human rights (1975-93)}

This section considers international influences on the emergence of the issue of women's land inheritance and how it has been built up as a public problem.

It was during a conference organised in Berlin in 1975, in the context of the 'International Year of Women' launched by the United Nations, that women members of the Union des Femmes Burundaises (UFB, the Burundi Women's Union), the female branch of the singleparty Union pour le Progrès National (UPRONA, the Union for National Progress, originally pro-Tutsi), initiated a movement to promote the adoption of a law on land inheritance. Before that date, land inheritance had been brought only sporadically on the agenda and always in the context of trials. ${ }^{\mathrm{vi}}$ Indeed, international conferences constituted platforms for the emergence of women's movements and sites of collaboration between women activists of the south. Likewise, in the 2000s, several regional conferences were organised on the land issue ${ }^{\mathrm{vii}}$ and helped women's movements make their struggle visible as well as gather information and contacts (Moghadam 2000). This timing cannot be attributed to pressure from international donor agencies or financial institutions but was rather due to UFB women's ability to take advantage of opportunities provided by a global context promoting the role of women in development. Moreover, while the international and regional levels helped the women's movement to emerge, it was essentially at a national level that women activists focused their action, lobbying legislative actors. As a result, from 1977 to 1993, land inheritance was the object of several multi-sectoral legislative commissions. In 1983, the first draft code on the persons and the family included a chapter on inheritance, matrimonial regimes and gifts, which was nevertheless not confirmed by the final draft (ACORD 2012, 5). Finally, between 1991 and 1993, the legislative national commission prepared a draft law on inheritance, matrimonial regimes and gifts, which was not submitted for adoption because of the political crisis of 1993.

The social construction of women's land inheritance as a public issue has been profoundly shaped by the global human rights discourse. Contrary to the case of Tanzania, this urban and educated female elite recognised in the 1970s 'the importance of land as their most valuable asset in a rural economy' (Manji 1998, 661) and mobilised international legal tools to put women's interests on the political agenda (interview, UN Women staff member (y), Bujumbura, February 2014).

Legal mobilisation can be explained by the particular context of the emergence of the UN Decade for Women, in combination with the absence of national legal tools promoting gender equality at the time. The education of women of the UFB sheds light on the use of this particular mode of action: most of these women had law degrees and worked as legal experts. For example, Marie-Christine Ntagwirumugara, one of the most active women on the issue of women's inheritance of land in Burundi, holds a bachelor degree in Law from the University of Burundi. Within the UFB, she first worked on drafting the second version of the code of persons and family. As a legal expert, she has mainly 'worked on women's rights, especially the right to inheritance' (interview, Marie-Christine Ntagwirumugara, Bujumbura, July 2012). 
Up till now, international legal tools and human rights have provided powerful political resources for women's movements (Goetz 2009, 64). For instance, the Convention on the Elimination of All Forms of Discrimination against Women (CEDAW), ratified in January 1992 by Burundi, is systematically quoted in civil society studies with the idea that Burundi has 'to respect international instruments once ratified' (interview, ex-coordinator of the Giriteka project at CARE International and member of AFJB, Bujumbura, March 2013). The Burundian implementation of CEDAW must be evaluated every four years. On these occasions, CSOs publish a shadow report - often funded by UNIFEM/UN Women - that systematically highlights the lack of political will concerning the land issue (2001, 2008 and 2013). From that perspective, 'appeals to human rights are often useful in putting pressure on states to redress acts of violence against women, particularly when local measures and national instruments have seemingly failed them' or do not exist (Steans 2007, 23; see also Tarrow 2001).

\section{Women's social mobilisations and the civil war: a missed opportunity (1993-2002)}

Following Buyoya's democratisation reforms in the late 1980s and attempts at tackling the impoverishment caused by civil war (1993-2006), many CSOs were created in the 1990s. As a result, new associations started addressing land inheritance in line with the human rights framework. Women's associations such as Association pour la Promotion de la Fille Burundaise and Réseau Femmes et Paix; and human rights associations such as La Ligue Iteka and the Association pour la Paix et les Droits de l'Homme took a public stance and published reports on the land issue. The Association des Femmes Juristes du Burundi (AFJB), founded by former members of the UFB in 1995, focused its action on inheritance and became the lead association on the issue. It started working on a draft law in cooperation with legislative commissions and the parliament in the late 1990s (interview, founding member of AFJB, Bujumbura, March 2014). During this period, international actors, particularly UNIFEM in the late 1990s, contributed to closer links between women from different political parties (mainly Front pour la Démocratie au Burundi, FRODEBU, the Front for Democracy in Burundi, the historical Hutu party, and UPRONA) and ethnic origins, providing 'neutral' sites of meeting where they could meet and develop joint strategies (interview, UN Women staff member (y), Bujumbura, July 2012). However, women of the CNDD-FDD, at that time a rebellion hidden in the bush, were not included in these meetings. This might explain the absence of links between women activists and women in politics when the CNDD-FDD came to power in 2005.

Despite alliances between women and collaboration between the activist social space and the legal system, attempts to codify inheritance repeatedly failed. In 1993, the civil war halted the process of adoption of the draft legislation on inheritance, drawn up by a national commission between 1991 and 1993. The issue was only returned to the legislative agenda 10 years after that. However, the new post-war transitional regime did not offer any opportunities for the issue to be addressed, unlike in the cases of Eritrea and Rwanda. Therefore, "[n]o matter how momentous a change appears in retrospect, it only becomes an "opportunity" when defined as such by a group of actors sufficiently well organised to act on this shared definition of the situation' (McAdam, McCarthy, and Zald 1996, 8). 


\section{Second phase: unfruitful cooperation between social activists and political institutions (2002-11)}

The legislative campaign went through ups and downs during the post-war period, highlighting resistance from men in power. This was despite alliances between women from the political and civil society spheres, and the direct involvement of international actors.

In the early $2000 \mathrm{~s}$, failure to adopt a law on women's land inheritance was interpreted by women of the elite in terms of male domination: 'In our view, this failure is due to the fact that men, who are the only decision-making authorities, want to keep women in permanent and total dependence' (Burundian delegation in Compte rendu de la Conférence sous-régionale 2001, 17). Adopting a law on women's land inheritance became thus an issue of 'gender equality' and intended 'to meet the deep aspirations of a female population lengthily excluded' (Draft law on inheritance, Matrimonial Regimes and Gifts 2004, 5). In 2002, supported by the United Nations Population Fund and UNIFEM, the AFJB collaborated with the parliamentary committee in charge of population issues in the drafting of the law on inheritance, matrimonial regimes and gifts (ACORD 2012; ONU Femmes 2014). It was a member of the AFJB who introduced this draft to the National Assembly, where it was examined in January 2004 before being sent to the government. This collaboration can be explained by women activists' ability to build alliances with women in politics, members of the FRODEBU and the UPRONA - the main historical political parties. Indeed, despite diverse partisan and ethnic origins, all these women went to the University of Burundi and started their militant career in the civil society, mainly the AFJB and the Collectif des Associations et ONG Féminines du Burundi (CAFOB), the oldest and biggest women's collective in Burundi. Until the mid 2000s, they also exercised political mandate and held important positions (as Member of Parliament, Senator, President of the Constitutional Court or Governor). Among these women, Marie-Christine Ntagwirumugara, Catherine Mabobori, Sabine Sabimbona, Domitille Barancira and Vestine Mbundagu were the most significant figures in the drive for women's rights in the early 2000s. Alliances between these women, acting in legal, political and civil society spheres, enabled them to lobby the legal system and to put women's interests on the public agenda:

UPRONA and FRODEBU were in the decision-making body, and within them, there were women from civil society, who then joined political parties. At the time, we were doing a good job. Because they came and gave us information in terms of lobbying: 'here, she's the one who's blocking things, there, it is him...' They told us: 'this is how it's going to be' and us, we were starting to take action. We were working together. (Interview, president of CSO network, Bujumbura, February 2014)

The CSO president's words should be placed in the context of the interview. In 2014, UPRONA and FRODEBU were opposition parties. Paying tribute to these alliances is a way of delegitimising the way women from the CNDD-FDD have handled the issue over recent years. However, there is no denying that apart from the issue of women's land inheritance, the first half of the 2000s saw important progress concerning the condition of women that we can attribute to women's alliances and lobbying of the legal and political systems. For example, the provision of a 30\% quota of women in the Constitution adopted in 2005 is the result of women's fight for their political participation during the Arusha peace negotiations (Daley 2007). Rwanda is another successful case of women's alliances in pushing for women's claims. Interestingly, it was promoted as such by international and Burundian actors, as illustrated during a learning experience visit made by a Burundian delegation to Rwanda in September 2012. The Rwandan Succession Law of 1999 was interpreted as the result of a fruitful collaboration between women parliamentarians, the Women's ministry and national and 
grassroots women's organisations. Beyond that, it showed the ability of women's movements to build broad coalitions with powerful actors a priori resistant to women's land rights such as the church, local public administrators, and men in politics (Interview CARE International staff member (x), Bujumbura, March 2013). Furthermore, the determined efforts on the part of the new Rwandan government to support gender equality should also be taken into account to understand the adoption of the law, which is not the case in Burundi, to the detriment of women activists: 'At a political level, women can do a lot of things, but it only works when the government and the parliament cooperate with civil society organisations and communities' (interview, president of a women's network, Bujumbura, August 2012).

Despite women activists' alliances and collaboration, and despite apparent political willingness, the issue of women's land inheritance was put aside and did not lead to a vote. After the elections of 2005, the government took a favourable position on women's land inheritance. Indeed, on International Women's Day on 8 March 2006 at Mwakiro (Muyinga Province), the President himself, Pierre Nkurunziza, promised that a law regarding equality between girls and boys in inheritance matters would very soon be passed. But this declaration did not bring the process back on track. On the contrary, legislative operations contributed to slowing it down. In May 2006, the Council of Ministers examined the proposition without adopting it and proposed instead to translate it into Kirundi to raise community awareness. In June 2007, the Ministry in charge of gender organised an informal meeting with some donors and $\mathrm{UN}$ agencies to request financial support for massive awareness activities, but the initiative was postponed to 2011 (ACORD 2012, 5). Women's associations, for their part, had started to diversify their mission and aims, and added many more goals into their plans, which led to a diminution of energy and resources dedicated to the land issue. Indeed, in the early 2000s it was the issue of sexual violence that became the object of intense attention from the government and women's associations. Just as in other contexts, it also attracted most international funds dedicated to gender issues in Burundi (interview, UN Women staff member (x), Bujumbura, July 2012).

That being the case, the process seemed to be back on track again in the early 2010s. Along with the political and legislative process, international actors stepped up their activities on land inheritance by funding awareness campaigns and studies, organising workshops and facilitating the establishment of the coalition of CSOs under the presidency of the AFJB and the vicepresidency of ACORD Burundi, and supported by CARE International. CARE International also implemented a specific project at the community level (the Giriteka project). In spring 2011 , the civil society coalition prepared a joint plan of action with the government. On 12 July, the government via the Ministry in charge of gender launched a campaign for the implementation of the joint action plan. The campaign took place between 25 and 30 July 2011 and public awareness activities were conducted.

\section{Third phase: after the presidential block on action, how (not) to bury an issue (2011-15)}

These activities were suddenly halted by a presidential intervention on the occasion of a speech on transitional justice on 28 July 2011, in Kayanza. During his speech, Pierre Nkurunziza called into question the process of adoption of the law, raising concerns over the risk of ethnic and land conflicts. This speech appeared as a sudden turnaround from those in power for the women activists, women in politics and institutional actors that took part in the process. For example, a woman MP from the CNDD-FDD who participated in the awareness-raising campaign told me of her surprise (interview, CNDD-FDD MP, Bujumbura, March 2014). First, the President was not expected to talk about land inheritance that day and had not informed any institutional 
or social actor working on the issue. Second, no written decision was issued after the speech nor any document explaining the rationale behind this reversal. It thus appeared as a sudden reversal but was interpreted by many civil society activists as an electoral ruse in order not to scare CNDD-FDD's voters in rural areas, particularly men who might have been averse to a law on women's land inheritance. The Ministry in charge of gender, Clotilde Niragira, then recommended new public consultations and further study on the issue (interview, UN Women staff member (x), Bujumbura, July 2012).

A period of confrontation between CSOs and political actors and institutions followed. It had already started after the 2010 elections, when the main opposition parties decided to go into hiding. CSOs were left alone facing a state controlled by single-party rule. Their role of watchdog was thus increasingly called into question: they were even accused of taking a stand for the opposition every time their views diverged from those of the government. Women's land inheritance soon became a symbol on which the government did not intend to abdicate, pointing out the risks of political instability and socioeconomic division in an already fragile situation: a law would be more likely to contribute to future tensions, and even to civil war.

\section{International actors as a third party in the confrontation between women's associations and the state}

Interactions between international and national scales of action fuelled the politicisation of collective action on land inheritance. In other words, international actors did not only provide technical and material resources for national actors to advance their own interests on the agenda of women's land rights. They profoundly interfered in the Burundian political game as a third party between women's associations and the state. Their impact was even more critical as the political situation had been unstable and tense. But to escape the 'political' dimension of their intervention, they adopted ambiguous, and sometimes uncoordinated, strategies aiming at depoliticising the discourse on women's land inheritance, illustrating divergent points of view between international actors.

Two aspects are highlighted here: uses of legal mobilisation by both women's associations and the state; changing frames of interpretation.

First, women's associations and the state used legal mobilisation for opposing goals. On the one hand, the process of women activists' professionalisation, highly influenced by international actors, reinforced their position vis-à-vis the government: 'from 2010, tensions with the government increased. We thus sharpened our advocacy tools, denounced, reported problems, and published more sophisticated studies. Media broadcasted everything' (interview, woman activist (x), Bujumbura, July 2012). Unlike in the case of Tanzania (Manji 1998, 663), women's associations' approach to the issue proved to be quite sophisticated, articulating strong theoretical and empirical arguments. They carried out various studies on communities' perceptions, on the impact of such a reform on women and development in Burundi, or on how to adjust legal dispositions to women's land inheritance (Ntagwirumugara 2011; AFJB and AJCB 2012). Moreover, they were at the forefront of the debate playing a proactive role in reports and draft legislation. Yet, they have remained unable to convince political institutions to adopt this law.

On the other hand, the government has been exploiting the modes of action of women's associations to slow down the process. For example, reporting was a way for the authorities to show their willingness on the issue while taking no concrete action, as illustrated in this interview with a CNDD-FDD MP: 'On inheritance, we did research, we published reports, we are moving forward' (interview, CNDD-FDD MP, Bujumbura, March 2014). Furthermore, multiplying committees, focus groups and reports may be interpreted as a way to disperse 
energy and resources on the issue, and eventually, to bury it. The national study ordered by the government on 'The impact of the absence of a written law on inheritance, matrimonial regimes and gifts on men, women and community, and on the value added of the existence of such a law in Burundi', following the presidential speech in Kayanza, is a perfect example of political manoeuvring to push the issue aside. The title of the study clearly illustrates the government's unwillingness to adopt a law, by focusing on the impact of the absence rather than on the adoption of a law. But, as observed by a consultant on the land issue: 'this study ... is an unusual procedure at a legislative level. Usually, the Council of Ministers drafts the laws. We cannot subordinate this project to a study!' (Interview, consultant on women's land rights, Bujumbura, March 2014). However, by requiring the study as a precondition for international organisations, NGOs and CSOs to continue working on women's rights and access to land, the government placed UN Women, which funded the study, in a difficult position. UN Women could not directly oppose the government's requirement without creating a diplomatic incident, nor could it keep interacting with women's organisations, which had been criticising the UN agency for its incoherence and lack of political involvement and for neglecting their struggle since the presidential halt on progress (interview, AFJB president, Bujumbura, July 2012).

Second, through a change of framing, international actors tried to keep working on women's access to land, with ambiguous effects on the politicisation of the issue of land inheritance. Already since the mid 2000s, with the involvement in the issue of the UN and NGOs such as CARE International, ACORD, International Alert and the United Nations Development Programme, a new discourse began to be imposed: development and rural women's empowerment. This implied a shift in framing: from 'gender equality' to 'women's empowerment', and beyond, to the 'development' of Burundi. This trend was reinforced after the presidential speech when the human rights discourse appeared too polemical. Reframing women's land rights as a development issue was a strategy used by some international actors and women activists to de-politicise the campaign, or, in other words, to build an advocacy discourse that the authorities could oppose less. The UN Women representative summarised in 2014 the main aspects of this new framing:

Our message is to say that there will not be economic development for women, women's empowerment, the strengthening of women's rights [without this law]. We should do this not because they are women, not for humanitarian reasons... We should do it because women will benefit from it, as well as their partner, their family, the community and the whole country. Burundi will not achieve development goals without addressing this issue, without solving this problem. This is a 'win-win' situation. This is not a source of conflict but an opportunity to solve it. So we need to change the terms of this debate and steer it in this direction. (Interview, UN Women Representative, Bujumbura, March 2014)

This change of framing impacted the conception of programmes. For example, after the presidential speech, CARE employed a new language and strategy to keep working on women's land rights: 'inheritance' was turned into 'equity in resource access and opportunities' (interview, CARE International staff member (y), Bujumbura, March 2014). Furthermore, modes of action needed to be changed. At the end of January 2013, the coalition of CSOs organised a gathering of its members in Mwaro to adopt new strategies and an action plan. Like in Uganda, '[t]he women's lobby quickly learnt to tailor its messages in terms of achievement of macro-economic development goals, and political imperatives, rather than focus exclusively on issues of equity, which had limited appeal to policy makers and legislators' (Goetz and Hassim 2003, 180). Legal mobilisation and mass awareness (Burundian delegation in Compterendu de la conference sous-régionale 2001, 17) tended also to be replaced by a terminology that would involve more international actors being seen as 'neutral': the terminology of advocacy. This term borrows from the vocabulary of international organisations and NGOs, 
thus from global normative and institutional discourse. It is descriptive of particular practices employed in development, human rights and peacebuilding fields (see Siméant 2014), then adapted to the Burundian campaign on women's land rights. Finally, while workshops, panels and meetings were still being organised on the land issue, they lost their relevance in bringing women closer to each other, whether they worked for international organisations, were involved in associations or were women in politics. They nevertheless remained social spaces where the issue could be put on the table, although framed differently, and conflict could express itself.

However, one important consequence of framing the issue with a development discourse is that it reoriented action on 'vulnerable' women. During the preparation of the first draft of the study ordered by the government, some women activists, who participated in the investigation, agreed with UN Women that the objectives of a law on women's land inheritance should be restricted to 'vulnerable women' and their children only, allowing them a small piece of land, arguing that the time had not yet come for all women to have equal rights (interview, woman activist, Bujumbura, March 2014). Then, for a short period, the idea put forward by UN Women was to target only women who had previously bought land, thus the most privileged categories of women. However, other organisations in the civil society coalition, such as CARE, did not support UN Women's stance and referred to the old framing (of 'gender equality') and modes of action ('appeal to jurisprudence or human rights associations'), condemning UN Women's suggestion with the comment that 'only accepting some snippets means going back in history' (interview, CARE International staff member (z), Bujumbura, March 2014).

While CARE did not publicly contest the UN Women strategy, their central position in the advocacy coalition is very likely to have convinced other civil society members of the necessity of a law for all women. UN Women finally backtracked. Their reputation could indeed have been damaged, as a staff member told me: 'it could have been poorly looked upon had UN Women promoted a "law on the cheap" (informal conversation, 2014).

To sum up, the politics of de-politicisation have had the unintended consequences of raising new debates, highlighting disrupted political configurations and changing systems of alliance among actors, groups and individuals.

\section{Changing political configurations and systems of alliance and support}

While the vast majority of people interviewed claimed to be individually in favour of a law on women's right to inherit land, debates over the correct framing and modes of action on women's rights and access to land revealed divergent positions between and within actors and groups.

On the one hand, debates illustrated changing alliances between women in political or partisan and civil society spheres. Women activists interpreted the block on progress as the result of divisions between women in politics (members of the CNDD-FDD) and women activists. They lamented the lack of engagement of women in politics on gender issues. On the contrary, for women in politics, the main obstacle to the adoption of a law lay in male resistance to women's inheritance, as a woman MP from CNDD-FDD argued: 'Men don't understand. We had many meetings on the topic, small ones, big ones, within the country: on that issue, things got too hot! Even among more educated men!' (interview, CNDD-FDD MP, Bujumbura, March 2014). There is no denying that the political exploitation of the issue constrained the emergence of women's voice within the political sphere.

On the other hand, the debates exacerbated the disconnection between an urban and educated female elite, supported by international actors, and rural women who were still absent from most international projects. Nevertheless, one must be careful when analysing this disconnection, as opponents of the law used it as an argument to undermine women activists' credibility. They were indeed criticised as 'intellectuals' who could not understand rural 
women's concerns: 'The [widespread] "opinion" would have us believe that the fight for gender equality in inheritance is a matter of educated women who, wrongly, try to influence rural women' (Ntagwirumugara 2011, 20). Like in the case of Tanzania, 'the origins of feminist groups and their membership of largely urban-based, middle-class women have limited their ability to engage with the issues which most concern rural peasant women' (Manji 1998, 661). Now, while feedback from the field highlighted resistance - linked with attachment to ancestral land and clan divisions, customary practices and patriarchal mentalities, they also showed a desire for the kind of social change already in practice in some families that allowed their daughter or sister to inherit (see ACORD 2012). As Ambreena Manji observed, '[w]omen's relations to land are complex. They are governed by their roles as food producers for the home and often also for the market', so not only as 'mothers, sister and daughters capable of inheritance or of disposing of land by inheritance'. Thus, assuming that women's relations to land are confined to inheritance may underlie the many and diverse realities they actually experience (Manji 1998, 651-652). Whether this disconnection was real or perceived, what is clear is that alliances or divisions between women were built in order to legitimise or delegitimise collective action on land inheritance. In this respect, at the present time, women's associations, which are mostly based in Bujumbura, have missed the opportunity to create links with women's groups from the interior (the 'hills') as well as with other CSOs. Campaigning for a law on women's land inheritance, Burundian urban and educated women have struggled above all to be recognised and to participate in the political sphere as women and for women. But while legal mobilisation provided a basis from which women have promoted women's interests, 'it was not and could never be a substitute for action on political, social and economic fronts to improve women's rights to land' (McAuslan 2010, 122).

\section{Conclusion}

Three aspects of collective action on women's land inheritance emerge from this study: the process of (de-)politicisation; contexts as social constructs; and methodological lessons on analysing the different levels.

First, in the conceptual framework section, we defined politicisation as a process of confrontation and negotiation with state authorities. This article has clarified the social mechanisms of this process. On the one hand, the study of legal mobilisation as a repertoire of action used strategically by various actors has showed that it can be a source of politicisation, with different implications over time: institutional politics, contentious politics and political domination. Legal mobilisation has had ambiguous effects on the result of women's collective action on land inheritance: it can be at the same time a factor of success and an obstacle for the integration of women's issues. On the other hand, international actors have influenced these dynamics indirectly, through standards and funding, and directly, by dedicating specific programmes to the land issue. They have shaped every dimension of women's collective action: framing (from human rights to the discourse of empowerment and development); modes of action (from lobbying the legal system to advocating political power); and goals (from legislative reform to improving women's access to land). Nevertheless, this evolution has not been linear; it has instead been characterised by overlapping framing, modes of action and goals, thus adding complexity to women's collective action as well as uncertainty as to its results. Furthermore, international actors have played an ambivalent but crucial role in the political game. By producing doubt and ambiguity on the appropriate representations and practices in women's land rights, they have indeed opened up a space where conflicts flourish, where political domination can be negotiated, legitimised or contested. Finally, the dynamics of de-politicisation should be analysed together with politicisation. In other words, de- 
politicisation as a strategy to neutralise the polemical dimension of women's land inheritance might have had the unintended effect of highlighting and deepening cleavages among actors, groups and individuals, and even of radicalising more positions on the issue, that is to say, of re-politicising it.

Second, the Burundian case shows that context should be considered not only as a social reality, constraining actors' behaviour, but also as a construct. Indeed, the act of naming and defining the situation is a way for actors to legitimise their position. Women's associations have seen 'post-war' as a context to push for legislative change. But the government has not shared this definition. By highlighting political tensions and social conflicts in this type of context, the government justified its block on the issue. It appears as a measure for not endangering 'peace' and 'security'. Furthermore, the government seems to be the most powerful actor in the process. Indeed, although it is dependent on international funds, intensely lobbied and even opposed by women's organisations, it is still the body that decides on timing and on the rules of the game. Then, in light of the political violence that broke out in the 2015 electoral period, it seems that the prospect of a civil war has placed a block on women's activism and social mobilisation. International actors, for their part, reallocated most of their funds on issues relating to women's political participation in the electoral process. Therefore, success or failure is more than ever dependent on the support of decision-making authorities in a situation in which actors agree on the definition.

Last but not least, it appears from that study that interactions between international, regional, national and local levels are crucial in building women's collective action on land inheritance in Burundi. More systematic and explicit attention should thus be paid to those levels in future work on collective action. Several dimensions should be worth analysing: the articulation of interpretive frames and norms; the interaction between national debates and international agendas; and international actors as a lever for mobilising resources.

\section{Bibliography}

Abrahamsen, R. 2004. "The Power of Partnerships in Global Governance." Third World Quarterly 25 (8): 1453-1467.

ACORD. 2012. Partager et grandir: bonnes pratiques en matière de succession. Bujumbura: Intermon Oxfam, Eusko Jaurlaritza Gobierno Vasco.

Association des Femmes Juristes du Burundi and Association des Juristes Catholiques du Burundi. 2012. "Impact du vide juridique observé en matière des successions, des régimes matrimoniaux et des libéralités." RML rapport final.

Berdal, M. R., and A. Suhrke, eds. 2012. The Peace in between: Post-war Violence and Peacebuilding. London; New York: Routledge.

Bereni, L., S. Chauvin, and A Jaunait. 2008. Introduction aux gender studies : manuel des études sur le genre. Brussels: De Boeck.

Bush, R., and M. Szeftel. 2000. "Commentary: The Struggle for Land." Review of African Political Economy 27 (84): 173-180.

Compte-rendu de la Conférence sous-régionale sur « La femme et le droit à la terre en Afrique de 1'Est » (2001). Organised by EASSI, 29 to 31 October 2001, Bujumbura.

Cornwall, A., and D. Eade, eds. 2010. Deconstructing Development Discourse: Buzzwords and Fuzzwords. Rugby: Practical Action.

Cornwall, A., and J. Edwards, eds. 2014. Feminisms, Empowerment and Development: Changing Women's Lives. London; New York: Zed Books.

Daley, P. 2007. "The Burundi Peace Negotiations: An African Experience of Peace-making." Review of African Political Economy 34 (112): 333-352. 
Daley, P. 2008. Gender \& Genocide in Burundi: The Search for Spaces of Peace in the Great Lakes Region. Oxford: James Currey; Bloomington, IN: Indiana University Press; Kampala: Fountain Publishers; Nairobi: E.A.E.P.; Johannesburg: Jacana Media (African issues).

Daley, E., R. Dore-Weeks, and C. Umuhoza. 2010. "Ahead of the Game: Land Tenure Reform in Rwanda and the Process of Securing Women's Land Rights." Journal of Eastern African Studies 4 (1): 131-152.

Daley, E., and B. Englert. 2010. "Securing Land Rights for Women." Journal of Eastern African Studies 4 (1): 91-113.

Debos, M. 2013. Le métier des armes au Tchad : Le gouvernement de l'entre-guerres. Paris: Karthala.

Ferguson, J. 1994. The Anti-politics Machine: 'Development', Depoliticization and Bureaucratic Power in Lesotho. Minneapolis: University of Minnesota Press.

Fillieule, O., E. Agrikoliansky, and I. Sommier. 2010. Penser les mouvements sociaux : conflits sociaux et contestations dans les sociétés contemporaines. Paris: La Découverte.

Fuest, V. 2010. "Contested Inclusions: Pitfalls of NGO Peace-building Activities in Liberia." Africa Spectrum 45 (2): 3-33.

Goetz, A. M., ed. 2009. Governing Women: Women's Political Effectiveness in Contexts of Democratization and Governance Reform. New York; London: Routledge.

Goetz, A. M., and S. Hassim, eds. 2003. No Shortcuts to Power: AfricanWomen in Politics and Policy Making. London: Zed Books; Cape Town: David Philip.

Hearn, J. 1998. "The "NGO-isation" of Kenyan Society: USAID \& the Restructuring of Health Care." Review of African Political Economy 25 (75): 89-100.

International Crisis Group. 2014. Fields of Bitterness (I): Land Reform in Burundi. Executive

summary, Africa Report, 123. Accessed August 5, 2016 at https://www.crisisgroup.org/africa/central-africa/burundi/fields-bitterness-i-land-reformburundi.

Jad, I. 2007. "NGOs: Between Buzzwords and Social Movements." Development in Practice 17 (4/5): 622-629.

Kothari, U., and M. M. Minogue, eds. 2002. Development Theory and Practice: Critical Perspectives. Houndmills: Palgrave.

Manji, A. 1998. "Gender and the Politics of the Land Reform Process in Tanzania." The Journal of Modern African Studies 36 (4): 645-667.

McAdam, D., J. D. McCarthy, and M. N. Zald, eds. 1996. Comparative Perspectives on Social Movements: Political Opportunities, Mobilizing Structures, and Cultural Framings. Cambridge: Cambridge University Press.

McAuslan, P. 2010. "Personal Reflections on Drafting Laws to Improve Women's Access to Land: Is there a Magic Wand?" Journal of Eastern African Studies 4 (1): 114-130.

McCann, M. W. 1994. Rights at Work: Pay Equity Reform and the Politics of Legal Mobilization. Chicago: University of Chicago Press.

Moghadam, V. M. 2000. "Transnational Feminist Networks Collective Action in an Era of Globalization." International Sociology 15 (1): 57-85.

Naybor, D. 2014. "Land as Fictitious Commodity: The Continuing Evolution of Women's Land Rights in Uganda." Gender, Place \& Culture: 1-17.

Ntagwirumugara, M-C. 2011. Etude sur les causes profondes de l'opposition à la loi sur les successions sensibles aux inégalités de genre. Bujumbura: CARE International et CARE Autriche.

Nyarusage, V. 1999. Les droits de la femme et leur application au Burundi (1963-1996). Mémoire en vue de l'obtention du grade de licencié en Histoire, Dir. Bonaventure Bandira, Bujumbura: Université du Burundi. 
Oberschall, A. 1993. Social Movements: Ideologies, Interests, and Identities. New Brunswick, NJ: Transaction.

ONU Femmes. 2014. Note sur la loi sur les successions, les régimes matrimoniaux et les libéralités.

Reyntjens, F. 2006. "Burundi: A Peaceful Transition After A Decade Of War?” African Affairs 105 (418): 117-135.

Richmond, O. P., and A. Mitchell, eds. 2012. Hybrid Forms of Peace: From Everyday Agency to Postliberalism. Basingstoke; New York: Palgrave MacMillan.

Rock, J. 2000. "The Land Issue in Eritrea's Reconstruction \& Development." Review of African Political Economy 27 (84): 221-234.

Siméant, J. 2014. "Interpreting the Rise of International 'Advocacy'." Humanity: An International Journal of Human Rights, Humanitarianism, and Development 5 (3): 323343.

Statistiques judiciaires burundaises. 2009. Rendements, délais et typologie des litiges dans les tribunaux de résidence. Bujumbura: RCN Justice \& Démocratie.

Statistiques du Recensement Général de la Population et de l'Habitat. 2012. Cadre Stratégique de Lutte contre la Pauvreté II.

Steans, J. 2007. “Debating Women's Human Rights as a Universal Feminist Project: Defending Women's Human Rights as a Political Tool." Review of International Studies 33 (1): 11-27.

Tarrow, S. 2001. "Transnational Politics: Contention and Institutions in International Politics." Annual Review of Political Science 4 (1): 1-20.

Tilly, C. 1978. From Mobilization to Revolution. New York: Random House.

Tripp, A. M., I. M. Casimiro, and J. C Kwesiga. 2009. African Women's Movements: Transforming Political Landscapes. Cambridge; New York: Cambridge University Press.

Uvin, P. 2009. Life after Violence: A People's Story of Burundi. London: Zed Books.

Vandeginste, S. 2009. "Power-sharing, Conflict and Transition in Burundi: Twenty Years of Trial and Error." Africa Spectrum 44 (3): 63-86.

\section{Interviews}

Marie-Christine Ntagwirumugara, Bujumbura, July 2012

President of a Women's network, Bujumbura, August 2012

Woman activist (x), Bujumbura, March 2014

President of AFJB, Bujumbura, July 2012

Founding member of AFJB, Bujumbura, March 2014

Member of Parliament (MP) of the CNDD-FDD, Bujumbura, March 2014

Consultant on women's land rights, Bujumbura, March 2014

UN Women Staff (x), Bujumbura, July 2012

UN Women Staff (y), Bujumbura, July 2012; February 2014

UN Women Representative, Bujumbura, March 2014

CARE International Staff (x), Bujumbura, March 2013

CARE International Staff (y), Bujumbura, March 2013

CARE International Staff (z), Bujumbura, March 2014

Ex-coordinator of Giriteka project at CARE International and member of AFJB, Bujumbura, March 2013 
${ }^{\mathrm{i}}$ Women are only the usufructuaries of land property. Single women, divorced women or widows can receive unequal pieces of land compared with those received by their brothers. They only exercise a life interest in this land, without any possibility of passing it down to their offspring.

ii Burundi has one of the highest population densities on the continent (about 400 people per square kilometre), with $90 \%$ of the population dependent on agriculture. The population is growing at a rate of $3.1 \%$ (data for 2013: http://donnees.banquemondiale.org/indicateur/SP.POP.GROW, accessed December 13, 2014). As a report of the International Crisis Group notes: 'bad land governance is deeply rooted and old regulation mechanisms are obsolete, thus contributing to conflict, social tensions and a malnutrition rate close to $75 \%$ ' (International Crisis Group 2014). In 2012, 80.2\% of Burundians owned land but only 17.7\% of women had access to land ownership compared with $62.5 \%$ of men (Statistiques du Recensement Général de la Population et de l'Habitat 2012, 58). Ninety per cent of land certificates established by communal services are on behalf of men.

iii Collective action is defined as 'the product of interactions, mutual perceptions, and expectations, called strategic intervention' (Oberschall 1993, 3). 'Women's collective action' refers to the collective action of women (composition of groups), as women (identity building) (I take inspiration from the definition of the 'women's movement' in Bereni, Chauvin, and Jaunait 2008, 164), for women. Indeed, in Burundi, collective action on land inheritance is mainly composed of women (mostly urban and educated women members of human rights and women's associations, and women in politics) who defend this right as women, but without labelling themselves as 'feminist' - a term that is perceived as too close to Western movements; and for women, especially for rural women who are primarily affected by the absence of this right.

${ }^{\text {iv }}$ I conducted about 20 in-depth interviews with Burundian women activists and women in politics as well as with UN and NGO employees (whose identity I do not always give for reasons of confidentiality). Taking advantage of two internships - at UN Women in 2012 and at CARE International in 2013 - I led observations and collected information on informal and sometimes 'hidden' processes of collective action. I also drew upon archival data from the UN, NGOs and CSOs as well as press articles.

${ }^{v}$ This is not to say that there is not an international agenda on women's inheritance to land: on the contrary: 'women's property and inheritance rights have been identified as a global strategic priority to meet Millennium Development Goal 3 ("Promote gender equality and empower women") at the Millennium Summit +5 in 2005 (United Nations 2012)'; also 'the Convention for the Elimination of all Forms of Discrimination Against Women (CEDAW) called for 'agrarian reform and redistribution of land to ensure the right of women, regardless of marital status, to share redistributed land on equal terms with men' (Naybor 2014, 892).

${ }^{v i}$ According to Virginie Nyarusage, in 1945, the chefferie tribunal recognised the right of women to inherit from their father, on condition that he had decided accordingly during his life. In 1964, Burundi's Cour de Cassation (Cour of Appeal) recognised the right of single, widowed or divorced women to inherit (Nyarusage 1999).

vii Such as the Eastern Africa Sub-Regional Support Initiative for the Advancement of Women (EASSI) subregional conference in 2001, and, 10 years later in Nairobi, a conference on the right of African women to land, with the participation of the Collectif des Associations et ONGs Féminines du Burundi (CAFOB). 